\title{
THE RELATIONSHIP OF CLEAN AND HEALTHY LIFE BEHAVIOR TO ILLNESS IN TODDLERS
}

\section{Lailatul Fitria ${ }^{1}$ Irwanto $^{2}$, Wahyul Anis ${ }^{3}$}

${ }^{1}$ Midwifery Program, Faculty of Medicine, Airlangga University, Surabaya, 60131

${ }^{2}$ Departement of Child Health, Faculty of Medicine, Airlangga University, Surabaya, 60131

${ }^{3}$ Midwifery Departement, Faculty of Medicine, Airlangga University, Surabaya, 60131

\section{INFORMASI ARTIKEL:}

\section{Riwayat Artikel:}

Tanggal diterima: Maret 2021

Tanggal di revisi: Maret 2021

Tanggal di Publikasi: April 2021

Key Word: Clean and Healthy Behavior, The Incidence of Illness

\section{A B S T R A C T}

Background: Childhood is susceptible to disease. One cause of illnesses in infants is due to unhealthy environmental conditions. Therefore, health efforts need to be done to prevent the emergence of diseases caused by the environment by behaving clean and healthy (PHBS). Method: observational analytic case control design. The number of samples was 142 toddlers with 71 respondents each in the case and control groups selected by consecutive sampling technique. Data were collected using questionnaires and illness reports from the health center. Data analysis used Chi Square with. Results: Chi Square test results with $5 \% \alpha$ indicated delivery assisted by health workers (cannot be analyzed), exclusive breastfeeding ( $\mathrm{p}=0.00$ ), washing hands with soap and water $(\mathrm{p}=0.00)$, eradicating larvae once a week $(\mathrm{p}=0.00)$, not smoking at home $(\mathrm{p}=0.00)$, and healthy life behavior $(\mathrm{p}=0.00)$. Conclusion: there was a relationship of exclusive breastfeeding, washing hands with soap and water, eradicating larvae once a week, and not smoking in the house to the incidence of illness in infants 


\section{INTRODUCTION}

Toddlers are a period that is prone to disease (Deapatih, 2017). The level of morbidity has an important role for toddlers in addition to the mortality rate. A high morbidity rate will trigger death, causing a high mortality rate as well (Suharwati, S, Fatcham A, Budijanto. 2013). Based on the 2013 Hospital Information (SIRS) data, the top three diseases that cause morbidity and mortality from outpatients in toddlers are acute upper respiratory tract infections (86,150 cases), fever of unknown causes (41,264 cases), and diarrhea (33,100 cases) (Ministry of Health of Indonesia Republic, 2015).

According to Blum's theory, the factors that play an important role in determining the degree of health are behavior, environment, quality of health care and genetics. Unhealthy behavior can cause various diseases. Likewise, unhealthy environmental conditions are a factor that causes high morbidity rates in an area. Behavior change is not easy to do but it is very necessary to improve the health status of the community. Therefore, it is necessary that health-based efforts must be made to prevent the emergence of diseases caused by environmental factors by way of people living clean and healthy (PHBS) (Tuban Health Office, 2017). The implementation of PHBS starts from the smallest community unit, i.e., the household.

The results of PHBS monitoring through the PHBS survey of Households in East Java in 2017 showed that $59.2 \%$ of households had done PHBS. When the results are compared to the report of the year 2016, i.e., reaching $53.82 \%$, there was an increase of $5.38 \%$. Meanwhile, in Tuban Regency, of 94,764 $(26.5 \%)$ out of a total of 357,200 households, 74,839 (79\%) were monitored to perform PHBS. PHBS coverage at the Temandang Health Center in 2017 has decreased since 2016 by $6.8 \%$. The number monitored was $1,530(20.5 \%)$ of 7,454 households, of which $966(63.1 \%)$ performed PHBS (Tuban Health

*Korespondensi: E-mail : lailatulf1998@gmail.com
Office, 2017). This indicates that the PHBS household coverage map at the Temandang Health Center is still within yellow line and still needs to be increased to green line with a percentage of more than $70 \%$. A healthy household is a household in which all family members have a clean lifestyle by implementing ten indicators, i.e., delivery assisted by health workers, exclusive breastfeeding, weighing toddlers every month, using clean water, washing hands with water and soap, using healthy latrines, eradicating larvae at home once a week, eating vegetables and fruit every day, doing physical activity every day, and avoiding smoking in the house. The habit of washing hands with running water and soap before eating and after using toilet with clean water, doing physical activities, consuming fruits and vegetables every day and not smoking can minimize the risk of infection (Kemenkes, 2011).

Until now, the relationship between household's PHBS and the incidence of illness in toddlers has never been investigated in the work area of Temandang Health Center, Tuban Regency. It is hoped that, with this study, people will understand the importance of clean and healthy living behavior in the household and be able to apply it in their household so that the incidence of illness in family members is reduced.

\section{METHOD}

This observational analytic study used a case control research design. This study was conducted in the work area of the Temandang Public Health Center, Tuban Regency in March-May 2020. The population was all toddlers aged 12-59 months in the work area of the Temandang Health Center, Tuban Regency. The sample consisted of 2 groups, i.e., the case group and the control group, totaling 142 children under five. The case samples were some children under the age of 12-59 months in the working area of the Temandang Public Health Center, Tuban Regency with the inclusion criteria: the frequency of illness history from toddlers was more than 3 times in the past year, and had 
been treated at the health center in the last one year while the exclusion criteria were those with congenital abnormalities and with a history of low birth weight. The control samples were toddlers aged 12-59 months in the work area of the Temandang Public Health Center, Tuban Regency with inclusion criteria: the frequency of history of illness from toddlers was more than 3 times in the past year, and had been treated at the health center in the last one year. The exclusion criteria were toddlers with congenital abnormalities and toddlers with a history of low birth weight. The sampling technique was consecutive sampling and the data were analyzed using the chi-square test.

\section{RESULT AND DISCUSSION}

Based on the results of the study, 41 of 142 toddlers aged between 48-59 months. The majority of toddlers was male as many as 80 toddlers $(56.3 \%)$. Based on the mother's education, half of them had a senior high school education or the equivalent by 71 mothers $(50.0 \%)$. Based on their work, all mothers did not work or only a homemaker by 97 mothers $(68.3 \%)$. Almost all of them have health insurance by 94 respondents $(66.2 \%)$ and almost all of the houses used ceramic floors by 118 houses $(83.1 \%)$.

Table 2. Characteristics of Clean and Healthy Life Behavior

\begin{tabular}{|c|c|c|c|c|c|c|}
\hline \multirow{2}{*}{ Variable } & \multicolumn{2}{|c|}{ Yes } & \multicolumn{2}{|c|}{ No } & \multicolumn{2}{|c|}{ total } \\
\hline & $\mathrm{n}$ & $\%$ & $\mathrm{n}$ & $\%$ & $\mathrm{~N}$ & $\%$ \\
\hline Exclusive & 92 & 64,8 & 50 & 35,2 & 142 & 100 \\
\hline Breastfeeding & & & & & & \\
\hline $\begin{array}{l}\text { Wash hands } \\
\text { with soap and } \\
\text { water }\end{array}$ & 105 & 73,9 & 37 & 26,1 & 142 & 100 \\
\hline $\begin{array}{l}\text { Eradicating } \\
\text { larvae at } \\
\text { home once a } \\
\text { week }\end{array}$ & 89 & 62,7 & 53 & 37,3 & 142 & 100 \\
\hline $\begin{array}{l}\text { No smoking } \\
\text { in the house }\end{array}$ & 60 & 42,3 & 82 & 57,7 & 142 & 100 \\
\hline PHBS & 34 & 24 & 108 & 76 & 142 & 100 \\
\hline
\end{tabular}

Table 2 shows that 92 (64.8\%) of 142 children under five were given exclusive breastfeeding, 105 parents $(73.9 \%)$ washed their hands with water and soap, $89(62.7 \%)$ households eradicated larvae in the house, $82(57.7 \%)$ household members smoke in the house, and 108 households $(67 \%)$ were not classified as PHBS.

Table 3. Characteristics of Illness

\begin{tabular}{ccc}
\hline Category & Frequency & $\begin{array}{c}\text { Presentage } \\
(\%)\end{array}$ \\
\hline $\begin{array}{c}\leq 3 \mathrm{x} \text { in a } \\
\text { year } \\
>3 \mathrm{x} \text { in a } \\
\text { year }\end{array}$ & 71 & $50 \%$ \\
\hline Total & 71 & $50 \%$ \\
\hline
\end{tabular}

Table 3 shows that both under-five children who experienced illness or not in the last 1 year had a frequency of 71 children $(50.0 \%)$. The difference in history of illness between the two groups lied in the frequency of illness during the past year. The grouping of the incidence of illness in toddlers was specified by looking at the frequency of illness in the category of frequent or experiencing pain more than 3 times during the last year. The results obtained were that the history of the incidence of illness was more common in male toddlers. This was due to the habit of boys doing activities outside the home and being more active than girls. Based on the study conducted by Iskandar et al (2015), there was a relationship between gender and the incidence of ARI. Boys are more susceptible to ARI due to the activities of men who are more active than women, so that it is possible for boys to be exposed to the causative agent of ARI. From the results of the study, most of the types of illness in toddlers were dominant in the form of ARI and diarrhea.

Table 4. The Relationship of Exclusive Breastfeeding to the Incidence of Iness in Toddlers

\begin{tabular}{|c|c|c|c|c|c|c|c|}
\hline \multirow{3}{*}{$\begin{array}{c}\text { Exclusive } \\
\text { Breastfee } \\
\text { ding }\end{array}$} & \multicolumn{4}{|c|}{ Frequency of Illness } & \multirow{2}{*}{\multicolumn{2}{|c|}{ Total }} & \multirow{3}{*}{$\begin{array}{c}p \\
\text { value }\end{array}$} \\
\hline & \multicolumn{2}{|c|}{ Frequent } & \multicolumn{2}{|c|}{ Rare } & & & \\
\hline & f & $\%$ & f & $\%$ & f & $\%$ & \\
\hline Yes & 35 & 49,3 & 57 & 80,3 & 92 & 64,8 & \\
\hline No & 36 & $\mathbf{5 0 , 7}$ & 14 & 19,7 & 50 & 35,2 & 0,00 \\
\hline Total & 71 & 100,0 & 71 & 100,0 & 142 & $\begin{array}{c}100, \\
0\end{array}$ & \\
\hline
\end{tabular}




\begin{tabular}{|c|c|c|c|c|c|c|c|}
\hline \multirow{3}{*}{$\begin{array}{c}\text { Wash } \\
\text { Hands } \\
\text { With } \\
\text { Water } \\
\text { And } \\
\text { Soap } \\
\end{array}$} & \multicolumn{4}{|c|}{ Frequency of Illness } & \multicolumn{2}{|c|}{ Total } & \multirow[t]{3}{*}{$\underset{\text { value }}{p}$} \\
\hline & \multicolumn{2}{|c|}{ Frequent } & \multicolumn{2}{|c|}{ Rare } & & & \\
\hline & $\mathbf{F}$ & $\%$ & f & $\%$ & f & $\%$ & \\
\hline Yes & 40 & 56,3 & 65 & 91,5 & 105 & 73,9 & \\
\hline No & 31 & 43,7 & 6 & 8,5 & 37 & 26,1 & 0,00 \\
\hline Total & 71 & $\begin{array}{l}100, \\
0\end{array}$ & 71 & 100,0 & 142 & 100 & \\
\hline
\end{tabular}

Table 6. Relationship of eradicating larva once a week to the incidence of illness in toddlers

\begin{tabular}{|c|c|c|c|c|c|c|c|}
\hline \multirow{3}{*}{$\begin{array}{c}\text { Eradicate } \\
\text { Larva } \\
\text { Once A } \\
\text { Week }\end{array}$} & \multicolumn{4}{|c|}{ Frequency of Illness } & \multirow{2}{*}{\multicolumn{2}{|c|}{ Total }} & \multirow{3}{*}{$\begin{array}{c}p \\
\text { value }\end{array}$} \\
\hline & \multicolumn{2}{|c|}{ Frequent } & \multicolumn{2}{|c|}{ Rare } & & & \\
\hline & $\mathbf{f}$ & $\%$ & $\mathbf{f}$ & $\%$ & f & $\%$ & \\
\hline Yes & 34 & 47,9 & 55 & 77,5 & 89 & 62,7 & \\
\hline No & 37 & 52,1 & 16 & 22,5 & 53 & 37,3 & 0,00 \\
\hline Total & 71 & $\begin{array}{c}100, \\
0\end{array}$ & 71 & $\begin{array}{c}100, \\
0\end{array}$ & $\begin{array}{c}14 \\
2\end{array}$ & 100 & \\
\hline
\end{tabular}

Table 7. Relationship of not smoking in the house to the incidence of illness in toddlers

\begin{tabular}{|c|c|c|c|c|c|c|c|}
\hline \multirow{3}{*}{$\begin{array}{c}\text { No } \\
\text { Smoke In } \\
\text { The } \\
\text { House }\end{array}$} & \multicolumn{4}{|c|}{ Frequency of Illness } & \multirow{2}{*}{\multicolumn{2}{|c|}{ Total }} & \multirow[t]{3}{*}{$\begin{array}{l}p \\
\text { value }\end{array}$} \\
\hline & \multicolumn{2}{|c|}{ Frequent } & \multicolumn{2}{|c|}{ Rare } & & & \\
\hline & $\mathbf{F}$ & $\%$ & f & $\%$ & f & $\%$ & \\
\hline Yes & 11 & 15,5 & 49 & 69,0 & 60 & 42,3 & \\
\hline No & 60 & 84,5 & 22 & 31,0 & 82 & 57,7 & 0,00 \\
\hline Total & 71 & $\begin{array}{c}100, \\
0\end{array}$ & 71 & 100,0 & 142 & 100,0 & \\
\hline
\end{tabular}

Table 8. The relationship of PHBS to the incidence of illness in toddlers

\begin{tabular}{ccccccccc}
\hline & \multicolumn{4}{c}{ Frequency of Illness } & \multicolumn{2}{c}{ Total } & p value \\
\cline { 5 - 8 } PHBS & \multicolumn{2}{c}{ Frequent } & \multicolumn{2}{c}{ Rare } & & & \\
& f & \% & f & \% & f & \% & \\
\hline Yes & 1 & 1,4 & 33 & 46,5 & 34 & 23,9 & \\
No & 70 & 98,6 & 38 & 53,5 & 108 & 76,1 & 0,00 \\
Total & 71 & 100,0 & 71 & 100,0 & 142 & 100,0 & \\
\hline
\end{tabular}

The results of the analysis in table 4 show that the tendency of toddlers who experienced illness occurred in respondents who were not given exclusive breastfeeding. The results of statistical tests obtained $p$ value of 0.00 so that it can be concluded that there was a relationship between exclusive breastfeeding and the incidence of illness in toddlers. This study was in line with that conducted by Dewi (2013) that there was a relationship between exclusive breastfeeding and the frequency of illness in infants aged 6-12 months at the Seyegan Health Center, Sleman Regency.
The types of illness suffered by toddlers in this study were mostly diarrhea and ARI. Nonexclusive breastfeeding is one of the risk factors for ARI, especially in infants who are susceptible to infection. By breastfeeding, the immune system of toddlers is formed so that they are not susceptible to disease. Mother's milk other than as a source of nutrition can provide protection to the baby through the various immune substances it contains. Breast milk contains sufficient essential nutrients for infants and is able to overcome infection through phagocytic cell components and immunoglobulins. Babies who are exclusively breastfed will get all the advantages of breastfeeding and their nutritional needs are met to the maximum so that they are more resistant to infection are less prone to allergies and get sick less often (Sulistiyoningsih, 2011).

Based on the data in Table 5, toddlers whose households had a habit of washing their hands with soapy water rarely got sick. On the other hand, toddlers whose households did not wash their hands with soap and water often got sick. Statistical tests conducted obtained a $p$ value of 0.00 , which means that there was a relationship between washing hands with water and soap and the incidence of illness in toddlers. From the respondent's data, the average parents of toddlers who washed their hands with water and soap had the last education of high school or equivalent so that they easily received broad insights about hand washing practices and were easy to practice.

According to a study conducted by Purnomo (2016), there was a relationship between hand washing behavior and the incidence of illness, namely diarrhea. The better the hand washing behavior, the lower the incidence of diarrhea. Hand washing with water alone is not enough to kill disease-causing microorganisms. Based on the results of several studies, improving clean and healthy living behaviors such as washing hands with soap can reduce the risk of disease transmission. Another study by Radhika (2020) states that there is a relationship between the act of washing hands with soap and the incidence of diarrhea in toddlers. 
Based on Table 6, the results of statistical tests for larva eradication obtained a $\mathrm{p}$ value of 0.00 which means that there was a relationship between eradicating larvae at home once a week with the incidence of illness in toddlers. Households that did not eradicate larvae once a week were households whose toddlers often experienced illnes by $52.1 \%$. This is because eradicating larvae is associated with dengue disease. Households who do not eradicate larvae once a week because they think that in a week the bathtub/water tank still looks clean and mostly drains the water tank once every 3 weeks or when it looks dirty.

This study is in line with Azlina's (2016) study on the act of eradicating mosquito larvae associated with DHF. The act of eradicating mosquito nests at home and in the surrounding environment is an effort to prevent the development of larvae into adult mosquitoes so that the Aedes aegypti mosquito population is reduced and thus the risk of transmission of dengue disease is also reduced.

Based on Table 7, the statistical tests for not smoking in the house obtained a $\mathrm{p}$ value of 0.00 which indicates that there was a relationship between not smoking in the house and the incidence of illness in under-five children. This study found that generally the types of illness suffered by toddlers were ARI and diarrhea. Cigarette smoke is one of the causes of ARI. The more often family members smoke in front of toddlers, the more often toddlers get sick with ARI. This is because toddlers are susceptible to disease.

The study is in line with what was done by Salma, A Yudi and Vandri (2015) at Sario Health Center in Manado City that smoking in the house can cause illness in toddlers, i.e., ARI. Cigarette smoke from parents or residents of the same roof with toddlers is a pollutant in the house and will increase the risk of toxic substances to children. Continuous exposure will cause respiratory problems, especially aggravating the incidence of acute respiratory infections and lung disorders in adulthood.
Based on Table 8, there was a relationship between PHBS and the incidence of illness in toddlers with a $\mathrm{p}$ value of 0.00 . Most of the households were still not categorized as having PHBS because one of the 10 PHBS indicators was not fulfilled. In general, the indicators that have not been met are exclusive breastfeeding, washing hands with water and soap, eradicating larvae once a week, and not smoking in the house. Unhealthy living behavior will cause various diseases, especially toddlers because the toddler's immune system is still not fully formed.

This is in line with the research of Elvandari, et all (2018) with 140 respondents that there was a relationship between PHBS and child morbidity, with a p-value of $0.001<0.05$. PHBS is the main capital for the prevention of ARI. On the other hand, behavior that does not reflect a healthy life will cause various diseases.

A person's clean and healthy living behavior is closely related to improving the health status of individuals, families, communities and the environment. So that healthy behavior in everyday life will prevent individuals from various diseases, especially infectious diseases. This study is in line with Angraini (2014) that there was a relationship between PHBS and the incidence of diarrhea. Bad behavior will make a big contribution in causing diarrheal pain. Hygiene behavior is one of the targets for PHBS..

\section{CONCLUSION}

It can be concluded that there was a relationship of exclusive breastfeeding, washing hands with water and soap, eradicating larvae once a week, not smoking in the house, and healthy life behavior to the incidence of illness in toddlers.

\section{REFERENCE}

Azlina, Ayu et all. (2016). HubunganTindakan Pemberantasan Sarang Nyamuk Dengan Keberadaan Larva Vektor DBD di Kelurahan Lubuk Buaya. [online]. jurnal.fk.unand.ac.id , jka , 
article, download [diakses pada tanggal 23 Juni 2020 pukul 19.00].

Deapatih, M.C. (2017). Prevalensi Anak Stunting Akibat Kurang Gizi Usia 0-5 Tahun Berdasarkan Jenis Penyakit Infeksi dan Non Infeksi di RSUD Dr. Soetomo Surabaya. Skripsi. Universitas Airlangga.

Dewi, Lia K. (2013). Hubungan Pemberian ASI Eksklusif dengan Frekuensi Kejadian Sakit pada Bayi Usia 6-12 Bulan di Puskesmas Sayegan Kabupaten Sleman. [Online] diperoleh dari http://digilib.unisayogya.ac.id/619/1 Na skah\%20Publikasi.pdf.pdf [diakses pada tanggal 23 Juni 2020 pukul 15.35].

Dinas Kesehatan Kabupaten Tuban. (2017). Profil Kesehatan Kabupaten Tuban Tahun 2017. [online] Diperoleh dari https://www.depkes.go.id/resources/do wnload/profil/PROFIL_KAB_KOTA 2017/3523_Jatim_Kab_Tuban_2017.pd f. [diakses pada tanggal 29 September 2019].

Elvandari, Millyantri, et all. (2018). Hubungan Perilaku Hidup Bersih dan Sehat dengan Morbiditas Anak Usia 1-3 Tahun di Jawa Tengah. Journal Unsika. Pp 19-23. Diperoleh dari https://journal.unsika.ac.id. [diakses pada tanggal 8 November 2019].

Iskandar, et all. (2015). Hubungan Jenis kelamin dan Usia Anak Satu tahun Sampai Lima Tahun Dengan Kejadian Infeksi Saluran Pernapasan Akut (ISPA). Global Medical \& Health Communication. [online] https://ejournal.unisba.ac.id/index.php/ gmhc/article/view/1538 [diakses pada tanggal 30 Juni 2020 pukul 12.43]

Kementerian Kesehatan Republik Indonesia. (2011). Pedoman Pembinaan Perilaku Hidup Bersih dan Sehat. [online] Diperoleh dari http://promkes.kemkes.go.id/pedomanphbs [Diakses pada tanggal 24 September 2019]

Kementerian Kesehatan Republik Indonesia. (2015). Pusat Data dan Informasi
Kementerian kesehatan RI. [online] Diperoleh dari https://pusdatin.kemkes.go.id/.

[Diakses pada tanggal 01 Oktober 2019]

Purnomo, Rafri A. (2016). Perilaku Mencuci Tangan dan Kejadian Diare pada Anak Usia Pra Sekolah di PAUD Desa Kalikotes Klaten. Skripsi. Universitas Muhammadiyah Surakarta.

Radhika, Aulia. (2020). Hubungan Tindakan Cuci Tangan Pakai Sabun dengan Kejadian Diare pada Balita di RW XI Kelurahan Sidotopo, Kecamatan Semampir, Kota Surabaya. Medical Technology and Public Health Journal Volume 4 No. 1, March 2020. Pp 19.

Suharwati S, Fatcham A, Budijanto. (2013). Faktor-faktor yang Mempengaruhi Morbiditas balita di Desa Klampar Kecamatan Proppo Kabupaten Pamekasan [tesis]. Malang (ID): Universitas Negeri Malang. 